\title{
ANALISA PERFORMANCE MESIN PENGUPAS KAYU (ROTARY) PT. HENRISON IRIANA SORONG MENGGUNAKAN METODE INDEKS KAPABILITAS
}

\author{
Ashar $^{1}$, Irman Amri $^{2 *}$, Usran $^{3}$ \\ ${ }^{1}$ Dosen Program Studi Teknik Industri Universitas Muhammadiyah Sorong \\ ${ }^{2}$ Dosen Program Studi Teknik Industri Universitas Muhammadiyah Sorong, Kepala \\ Quaility Controll PT. Henrison Iriana Sorong \\ ${ }^{3}$ Mahasiswa Program Studi Teknik Industri Universitas Muhammadiyah Sorong \\ Jln. Pendidikan No 27 Kota Sorong, Papua Barat \\ "Email: irmanamri_srg@yahoo.com
}

\begin{abstract}
Abstrak
Penggunaan mesin dalam menghasilkan output produk yang berkualitas pada industri manufaktur, yang bergerak pada proses pengolahan kayu mentah (Loq) menjadi barang jadi (plywood), merupakan hal yang sangat efektif bagi suatu perusahaan dalam mancapai, meningkatkan, dan memenuhi kebutuhan pasar atau konsumen. Salah satu mesin yang digunakan pada industri plywood adalah penggunaan mesin rotary dalam melakukan proses produksi yang difungsikan untuk mengupas kayu loq menjadi lembaran-lembaran tipis (veneer). Dengan tingkat ketebalan veneer yang ditentukan oleh perusahan berdasarkan permintaan konsumen. Tahap pelaksanaan metode ini adalah dengan mengambil sampel hasil kupasan atau hasil proses produksi mesin rotary pada menit-menit yang telah ditentukan yang kemudian diinput pada cheksheet yang akan dilakukan pengujian kecukupan data, pengujian distribusi normal, yang selanjutnya dibuatkan peta kendali dan pengujian Indeks Capability Process (Cp). Sehing ga nilai Indeks Capability Process Cpk dan Cpm diketahui mesin rotary 4 ketebalan 1,70 mm pengukuran bagian kanan dengan nilai indeks Cpk 0,3324, pengukuran bagian kiri dengan nilai indeks Cpk 0,3531, pengukuran bagian tengah dengan nilai indeks Cpm 0,0023, pengukuran bagian panjang dengan nilai indeks Cpm 0,9203. Sedangkan ketebalan 2,50 mm pengukuran bagian kanan dengan nilai indeks Cpm 0,0079, pengukuran bagian kiri dengan nilai indeks Cpk 0,6226, pengukuran bagian tengah dengan nilai indeks Cpk 0,7102, pengukuran bagian panjang dengan nilai indeks Cpm 0,3203. Dan mesin rotary 6 ketebalan 1,70 mm pengukuran bagian kanan dengan nilai indeks Cpm 0,0027, pengukuran bagian kiri dengan nilai indeks Cpk 0,4521, pengukuran bagian tengah dengan nilai indeks Cpm 0,0026, pengukuran bagian panjang dengan nilai indeks Cpm 0,3642 sedangkan ketebalan 2,50 mm pengukuran bagian kanan dengan nilai indeks Cpk 1,0944, pengukuran bagian kiri dengan nilai indeks Cpk 0,8584, pengukuran bagian tengah dengan nilai indeks Cpk 1,0855 dan pengukuran bagian panjang dengan nilai indeks Cpm 0,3664. Dari nilai indeks capability process tersebut maka perlu dilakukan peningkatan proses pada tiap-tiap mesin rotary pengupas kayu loq.
\end{abstract}

Kata Kunci : Indeks Capability Process (Cp), Ketebalan veneer, Performance Mesin Rotary.

\section{PENDAHULUAN}

\subsection{Latar Belakang}

Pada sebuah perusahan besar seperti halnya pada PT. Henrison Iriana, yang bergerak pada proses pengolahan kayu mentah menjadi barang jadi (plywood) yang siap digunakan dan dipasarkan. Sudah hal yang wajib bagi pihak perusahan untuk menggunakan jasa mesin dan peralatan - peralatan dengan kapasitas besar, guna untuk menunjang hasil dan jalannya proses produksi yang dilakukan oleh perusahaan PT. Henrison Iriana.

Untuk menghasilkan produk yang berkualitas seperti yang diharapkan dari pihak perusahaan, sudah menjadi hal wajib yang perlu dilakukan oleh depertemen produksi untuk mengawasi atau mengontrol jalannya proses produksi. Baik itu berupa pengawasan terhadap penggunaan mesin produksi maupun hasil proses dari tiap-tiap mesin, guna untuk menghindari terjadinya kesalahan pada hasil proses produksi.

Mengingat mesin - mesin yang digunakan oleh PT. Henrison Iriana dalam melakukan proses produksi sudah cukup lama atau umur mesin yang sudah tua, sehingga hal ini dapat mempengaruhi kualitas produk yang dihasilkan PT. Henrison Iriana.

Pengendalian kualitas (Quality Control) perlu kiranya dilakukan pada mesin pengupas kayu (rotary). hal ini dikarenakan selain mesin tersebut merupakan alur utama proses produksi, mesin tersebut juga memiliki fungsi utama yaitu mengupas kayu menjadi lembaran-lembaran tipis (veneer). 
yang kemudian dari lembaran - lembaran veneer kayu tersebut akan dicetak menjadi tripleks (plywood) yang merupakan produk utama dari perusahaan PT. Henrison Iriana.

\subsection{Tujuan Penelitian}

Tujuan dari penelitian ini adalah :

1. Untuk mengetahui prosentase peta kontrol X-bar tingkat kerataan, kesesuaian dan ketepatan kupasan mesin tersebut.

2. Untuk mengetahui tingkat kapabilitas mesin tesebut

\section{METODOLOGI}

\subsection{Lokasi Penelitian}

Penelitian ini dilakukan pada perusahan PT. Henrison Iriana yang terletak di Arar, kabupaten sorong. Objek penelitian ditujuhkan pada mesin pengupas kayu (rotary) dan variabel yang diukur dalam penelitian performance mesin ini adalah data hasil proses produksi mesin pengupasan kayu (rotary) menjadi lembaran - lembaran veneer.

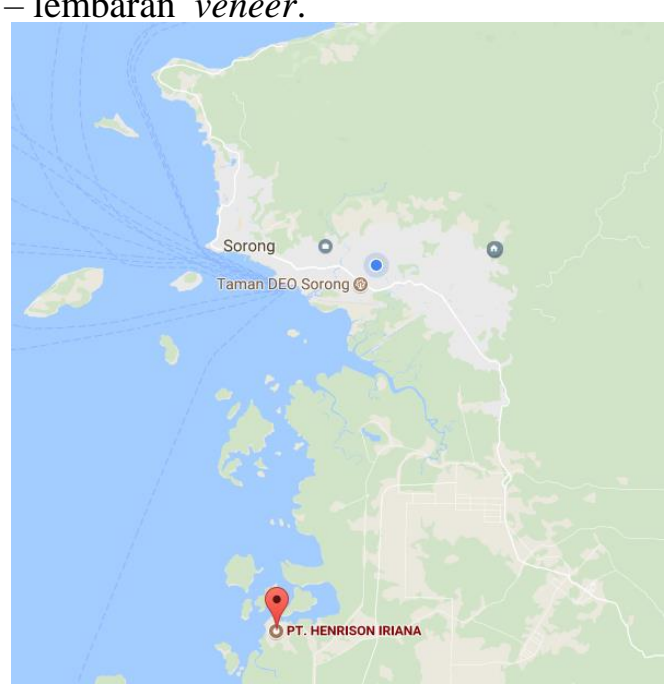

Gambar 1. Lokasi penelitian

\subsection{Metode Pengumpulan Data}

Didalam penelitian yang kami lakukan, kami mengumpulkan data-data yang sangat dibutuhkan di dalam penelitian ini. Adapun pengumpulan data yang digunakan sebagai berikut :

\subsubsection{Data primer}

Data yang diperoleh melalui penelitian langsung dilapangan berdasarkan objek yang diteliti, adapun pengumpulan data yang digunakan adalah dengan cara sebagai berikut:

1. interview

Dalam penelitian ini wawancara dilakukan pada kepala bagian produksi, Quality Control, dan operator dan mekanik mesin rotary untuk mengetahui sistem dan cara kerja dari mesin pengupas kayu (rotary). Serta proses-proses dalam pembuatan vinir (veneer).

2. Observasi

Dalam penelitian ini observasi dilakukan untuk mengamati karakteristik pada lembaran lembaran vinir (veneer) yang dihasilkan dan kerataan, keakuratan dan ketepatan kupasan dari mesin pengupas kayu (Rotary). Pengambilan data dilakukan dengan cara sebagai berikut:

a. Pengambilan data dilakukan pada dua mesin yakni; mesin rotary 4 dan mesin rotary 6 .

b. Pengambilan data dilakukan setiap 30 menit sekali dengan pengulangan pengambilan data sebanyak 20 kali pengulangan.

c. Setiap 30 menit pengambilan data variabel diambil sebanyak 5 variabel dari tiap - tiap mesin dengan cara pengambilan variabel secara random (acak).

d. Setiap variabel di pisahkan antara variabel mesin rotary 4 dan variabel mesin rotary 6 . Kemudian variabel - variabel tersebut diukur, data dari penguran inilah yang kemudian dicatat pada lembar cheksheet pengamatan. 
e. Pengukuran dilakukan dengan menggunakan alat ukur, yaitu; meteran untuk mengukur panjang veneer dan dligtan untuk mengukur ketebalan veneer.

\subsubsection{Data sekunder}

Pengumpulan data sekunder merupakan pengumpulan data secara tidak langsung dari sumber atau objek. Data sekunder yang diperoleh melalui kegiatan perpustakaan buku-buku, dan literature yang berkaitan dengan penelitian yang kami lakukan. Serta data-data umum dari manajemen perusahan berupa data-data pengendalian kualitas (quality control) satu bulan terakhir pada manajemen pengendalian kualitas di bagian produksi. Data yang dimaksudkan seperti batas - batas spesifikasi standar kualitas ketebalan veneer yang diharapkan oleh perusahaan dan data - data hasil pengukuran yang di lakukan oleh pelaksana quality control yang berkaitan dengan tingkat ketebalan.

\subsection{Teknik Pengolahan dan Analisa Data}

Pengukuran ini merupakan tahap lanjutan pengukuran dari pengukuran peta kendali (control), pengukuran ini dimaksudkan untuk memberikan gambaran sedehana antara hubungan variabilitas proses dengan batasan tebaran spesifikasi. Dan untuk mengetahui apakah proses kinerja pada objek penelitian menghasilkan output yang berada dalam batasan spesifikasi yang diharapkan.

Adapun rumus yang digunakan dalam melakukan pengukuran ini, ialah:

$$
\begin{array}{rll}
\mathrm{C}_{\mathrm{p}} & = & (\mathrm{USL}-\mathrm{LSL}) / 6 \mathrm{~s} ; \\
\mathrm{C}_{\mathrm{p}} & = & \mathrm{R}-\mathrm{bar} / \mathrm{d}_{2} \\
\mathrm{C}_{\mathrm{PK}} & = & \min (\mathrm{CPL}, \mathrm{CPU}), \\
\text { dimana: } & \\
\mathrm{CPL} & =(\mathrm{X} \text {-doubel bar }-\mathrm{LSL}) / 3\left(\mathrm{R}-\text { bar } / \mathrm{d}_{2}\right) \\
\mathrm{CPU} & =(\mathrm{USL}-\mathrm{X}-\text { double bar }) / 3\left(\mathrm{R}-\text { bar } / \mathrm{d}_{2}\right) \\
\mathrm{C}_{\mathrm{pm}} & =\frac{U S L-L S L}{6 \sqrt{\sigma^{2}+(\mu-T)^{2}}}
\end{array}
$$

\section{kriteria penilaian:}

a. Jika $\mathrm{C}_{\mathrm{p}}>1,33$, maka kapabilitas proses sangat baik.

b. Jika $1,00 \leq C_{p} \leq 1,33$, maka kapabilitas proses baik, namun perlu pengendalian ketat apabila $C_{p}$ mendekati 1,00 .

c. Jika $C_{p}<1,00$, maka kapabilitas proses rendah, sehingga perlu ditingkatkan kinerjanya melalui peningkatan proses itu.

\section{HASIL DAN PEMBAHASAN}

\subsection{Pengumpulan Data}

Sebagaimana yang telah didapatkan oleh peneliti dalam melakukan pengamatan secara langsung, pada objek yang diteliti yaitu mesin pengupas kayu (Rotary 4 dan Rotary 6), guna untuk mendapatkan data pengamatan yang sesuai dengan penelitian ini, dan untuk memastikan agar data yang diperoleh merupakan data aktual yang di perlukan dalam penelitian ini. Adapun data - data yang diperoleh peneliti antara lain sebagai berikut :

a. Data tingkat ketebalan mesin rotary 4 dengan tingkat ketebalan $1,70 \mathrm{~mm}$

b. Data tingkat ketebalan mesin rotary 4 dengan tingkat ketebalan $2,50 \mathrm{~mm}$

c. Data tingkat ketebalan mesin rotary 6 dengan tingkat ketebalan $1,70 \mathrm{~mm}$

d. Data tingkat ketebalan mesin rotary 6 dengan tingkat ketebalan 2,50 mm

\subsection{Pengolahan Data}

Adapun tahapan-tahapan yang dilakukan oleh peneliti dalam melakukan pengolahan data pengamatan sebagai berikut : 


\subsubsection{Uji test kecukupan}

Uji Test kecukupan data dilakukan pada data yang telah diambil secara langsung oleh peneliti dilapangan, pengujian ini untuk mengetahui tingkat kecukupan data dengan mempertimbangkan nilai tingkat kepercayaan $(\mathrm{K})$ sebesar $=95 \%$ atau $=2$, dan nilai tingkat ketelitian $(\mathrm{S})$ sebesar $=5 \%$ atau $=0,05$ sebagai parameter untuk mengetahui nilai kecukupan data penelitian. Dari hasil perhitungan data diatas dapat disimpulkan $\mathbf{N}{ }^{\prime}=\mathbf{1 , 1 4}<\mathbf{N}=\mathbf{1 0 0}$ maka, dengan demikian dapat dinyatakan bahwa pengambilan data mesin rotary 4 ketebalan 1,70 mm bagian kanan dikatakan cukup.

\subsubsection{Uji test distribusi normal}

Pada perhitungan uji distribusi normal peneliti menggunakan program Spss guna membantu peneliti dalam melakukan uji distribusi normal. Dengan hipotesis sebagai berikut:
a. Hipotesis
H0 : Populasi berdistribusi normal
H1 : Populasi tidak berdistribusi normal
b. Tingkat signifikansi
$\alpha=5 \%$ atau $\alpha=0,05$
Jika Signifikansi $<\alpha$ : tolak HO
Jlka Signifikansi $>\alpha$ : terima HO
Adapun data yang di uji kenormalan ialah sebagai berikut:

\section{Uji distribusi normal data pada mesin rotary 4 dengan ketebalan $1,70 \mathrm{~mm}$ bagian kanan, kiri,} tengah dan panjang.

Data dibawah ini adalah data yang sudah memenuhi syarat dalam kecukupan data pengamatan, data tersebut adalah data pengamata mesin rotary 4 dengan tingkat ketebalan 1,70 dari seluruh bagian pengukuran.

Berdasarkan nilai signifikansi tabel pengujian distribusi normal diatas, maka dapat disimpulkan nilai bagian Kanan $=0,241>0,05$ dan nilai bagian Kiri $=0,327>0,05$ maka hipotesis $\mathrm{H} 0$ diterima, sehingga data nilai pengukuran bagian kanan dan kiri dinyatakan berdistribusi normal. sedangkan nilai bagian Tengah $=0,021<0,05$ dan nilai bagian Panjang $=0,000<0,05$ maka hipotesis $\mathrm{H} 0$ ditolak, sehingga dapat dinyatakan bahwa pengukuran bagian tengah dan panjang data tersebut tidak berdistribusi normal.

\subsubsection{Peta kendali (control chart) X-bar dan R-bar}

Adapun pengujian data peta kendali X-bar dan R-bar hasil kupasan mesin rotary 4 dengan standar ketabalan 1,70 $\mathrm{mm}$ pada bagian kanan yang diperoleh dari hasil pengamatan sebagai berikut:

Tabel 1. Rata-rata X-bar dan R-bar rotary 4 ketebalan $1,70 \mathrm{~mm}$ bagian kanan

\begin{tabular}{|c|c|c|c|c|c|c|c|c|}
\hline \multirow[b]{2}{*}{$\begin{array}{c}\text { No } \\
\text { Sampel }\end{array}$} & \multicolumn{5}{|c|}{$\mathrm{N}$} & \multicolumn{3}{|c|}{ Perhitungan Yang Perlu } \\
\hline & $\mathrm{X} 1$ & $\mathrm{X} 2$ & X3 & X4 & $\mathrm{X} 5$ & Jmlh & $\begin{array}{c}\text { Rata-rata } \\
\text { (X-bar) }\end{array}$ & $\begin{array}{c}\text { Range } \\
\text { ( R ) }\end{array}$ \\
\hline 1 & 1,80 & 1,76 & 1,73 & 1,76 & 1,78 & 8,83 & 1,766 & 0,07 \\
\hline 2 & 1,78 & 1,82 & 1,75 & 1,72 & 1,84 & 8,91 & 1,782 & 0,12 \\
\hline 3 & 1,75 & 1,72 & 1,76 & 1,80 & 1,72 & 8,75 & 1,75 & 0,08 \\
\hline 4 & 1,74 & 1,83 & 1,80 & 1,74 & 1,72 & 8,83 & 1,766 & 0,11 \\
\hline 5 & 1,77 & 1,70 & 1,74 & 1,75 & 1,87 & 8,83 & 1,766 & 0,17 \\
\hline \multicolumn{6}{|c|}{ Jumlah } & 174,48 & 34,896 & 2,09 \\
\hline \multicolumn{6}{|c|}{ Rata-Rata } & & 1,7448 & 0,1045 \\
\hline
\end{tabular}

Sumber : Pengolahan Data $x$-bar Dan r-bar

Dari tabel diatas maka diketahui bahwa nilai $\mathrm{x}$-doubel bar $=1,7448$ dan untuk nilai $\mathrm{R}$-bar $=$ 0,1045 . Untuk melihat nilai koefisien dalam pembuatan peta Kontrol $\mathrm{x}$-doubel bar dapat dilihat pada (Tabel 4), sehingga diketahui nilai koefisien perhitungan batas peta kontrol X-bar dan R-bar, sebagai berikut:
$\mathrm{A}_{2}=0,577$
$\mathrm{D}_{3}=0$
$\mathrm{D}_{4}=2,114$
$\mathrm{d}_{2}=2,326$ 


\section{Maka :}

a) Peta kontrol X-bar penyelesaian:

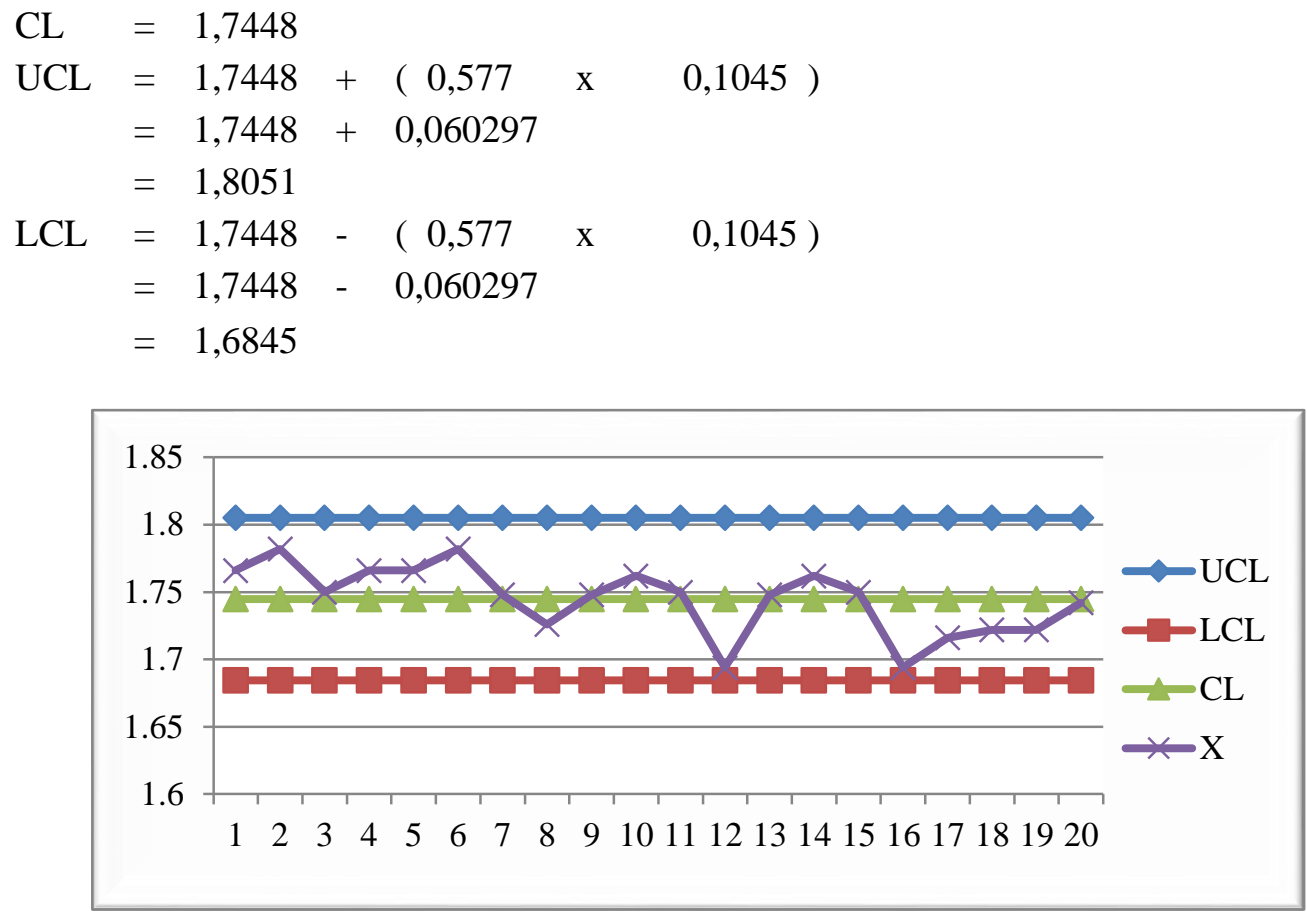

\section{Gambar 1. Peta kontrol X-bar rotary 4 ketebalan $1,70 \mathrm{~mm}$ bagian kanan}

Dari gambar peta kontrol x-bar diatas maka dapat disimpulkan bahwa perubahan data variabel ketebalan veneer berada dalam batas kontrol.

b) Peta Kontrol R-bar

Penyelesaian :

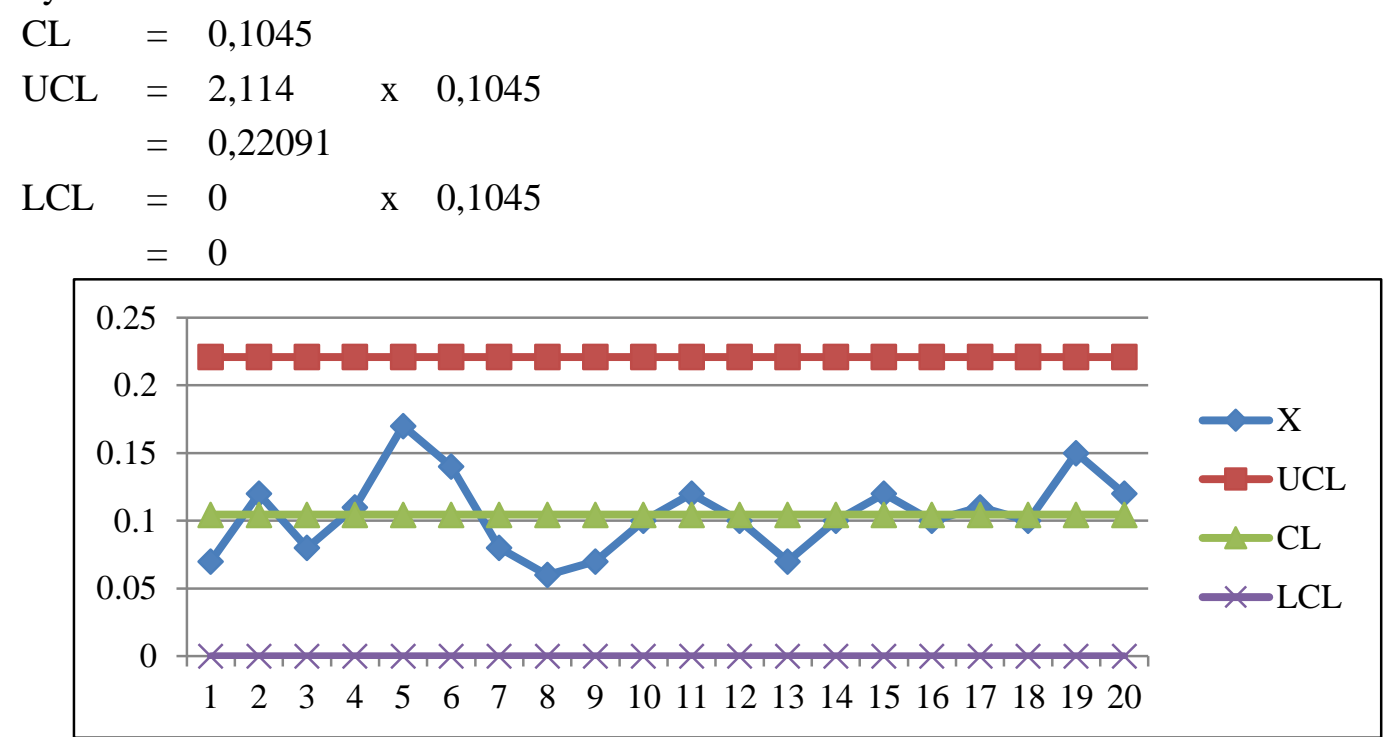

Gambar 2. Peta kontrol X-bar rotary 4 ketebalan 1,70 mm bagian kanan

Dari gambar peta kontrol R-bar diatas maka dapat disimpulkan bahwa data variabel ketebalan veneer berada dalam batas kontrol ukuran variasi ketebalan kupasan veneer. 


\subsubsection{Uji Indeks Kapabilitas Proses Cp dan Cpk}

Adapun nilai Target $(\mathrm{T})$ yang ditentukan oleh perusahan adalah standar ketebalan dengan tingkat ketebalan $1,70 \mathrm{~mm}$ dan nilai tingkat toleransi batas atas atau USL $=1,90 \mathrm{~mm}$ dan batas bawah atau $\mathrm{LSL}=1,70 \mathrm{~mm}$. dan nilai Target $(\mathrm{T})$ dengan tingkat ketebalan $2,50 \mathrm{~mm}$ dan nilai tingkat toleransi batas atas atau USL $=2,80 \mathrm{~mm}$ dan batas bawah atau $\mathrm{LSL}=2,40 \mathrm{~mm}$. sehinggah dapat dihitung nilai indeks kapabilitas proses untuk mesin rotary 4 dengan tingkat ketebalan 1,70 mm pengukuran bagian kanan, sebagai berikut:

$$
\begin{aligned}
& \mathbf{S}=0,1045: 2,326 \\
& =0,0449 \\
& \mathbf{C P}=\left(\begin{array}{lll}
1,90 & -1,70
\end{array}\right):\left(\begin{array}{lll}
6 & \mathrm{x} & 0,04493
\end{array}\right) \\
& =\left(\begin{array}{c}
0,2 \\
0,2696
\end{array}\right) \\
& =\mathbf{0 , 7 4 1 9} \\
& \mathbf{C P L}=\left(\begin{array}{lll}
1,7448 & - & 1,70
\end{array}\right):\left(\begin{array}{lll}
3 & \mathrm{x} & 0,04493
\end{array}\right) \\
& =\left(\begin{array}{l}
0,0448 \\
0,1348
\end{array}\right) \\
& =\mathbf{0 , 3 3 2 4}
\end{aligned}
$$

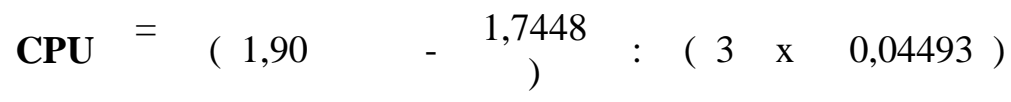

$$
\begin{aligned}
& =\left(\begin{array}{l}
0,1552 \\
0,1348
\end{array}\right) \\
& =1,1515 \\
& \mathrm{CPK}=0,3324
\end{aligned}
$$

Dari perhitungan di atas maka diketahui bahwa nilai Indeks $\mathrm{Cp}=0,3324<1,00$, maka kapabilitas proses rendah, sehingga perlu ditingkatkan kinerjanya melalui peningkatan proses.

\subsubsection{Uji indeks kapabilitas proses Cpm}

Adapun nilai Target (T) yang ditentukan oleh perusahan adalah standar ketebalan dengan tingkat ketebalan 1,70 $\mathrm{mm}$ dan nilai tingkat toleransi batas atas atau USL $=1,90 \mathrm{~mm}$ dan batas bawah atau $\mathrm{LSL}=1,70 \mathrm{~mm}$. dan nilai Target $(\mathrm{T})$ dengan tingkat ketebalan $2,50 \mathrm{~mm}$ dan nilai tingkat toleransi batas atas atau USL $=2,80 \mathrm{~mm}$ dan batas bawah atau $\mathrm{LSL}=2,40 \mathrm{~mm}$. sehinggah dapat dihitung nilai indeks kapabilitas proses untuk mesin rotary 4 dengan tingkat ketebalan 1,70 mm pengukuran bagian tengah, sebagai berikut:

$$
\begin{array}{rllll}
\mathrm{S} & = & 0,108 & : & 2,326 \\
& = & 0,0464 &
\end{array}
$$




$$
\begin{array}{ll}
\text { Cpm } & =\frac{1,90-1,70}{6 \sqrt{0,046^{2}+(1,7528-1,70)^{2}}} \\
& =\frac{0,20}{6 \sqrt{0,046^{2}+(0,0528)^{2}}} \\
& =\frac{0,20}{6 \sqrt{0,002+0,0028}} \\
& =\frac{0,20}{6 \sqrt{0,005}} \\
& =\frac{0,20}{6(0,07)} \\
& =0,0333(0,07) \\
& =0,0023
\end{array}
$$

Dari perhitungan di atas maka diketahui bahwa nilai Indeks Cpm $=0,0023<1,00$, maka kapabilitas proses rendah, sehingga perlu ditingkatkan kinerjanya melalui peningkatan proses.

\section{KESIMPULAN}

Dalam menarik kesimpulan berdasarkan bab - bab sebelumnya, maka dapat disimpulkan bahwa:

1. Proses pengupasan kayu pada mesin rotary 4 dinyatakan memiliki tingkat kerataan, kesesuaian dan ketepatan kupasan. Dengan presentase peta control X-bar sebesar 97,5\% berada dalam batas control dan 2,5\% berada diluar batas control. Sedangkan presentase pada peta control R-bar sebesar $94,4 \%$ berada dalam batas control dan 5,6\% berada diluar batas control. Adapun proses pengupasan kayu pada mesin rotary 6 dinyatakan memiliki tingkat kerataan, kesesuaian dan ketepatan kupasan. Dengan presentase peta control X-bar sebesar $91,3 \%$ dan $8,7 \%$ berada diluar batas control. Sedangkan presentase pada peta control R-bar sebesar 98,8\% dan 1,2\% berada diluar batas control.

2. Proses pengupasan kayu pada mesin rotary 4 dinyatakan tidak capabel (kemampuan proses rendah). Nilai kapabilitas tersebut terlihat pada proses pengupasan kayu dengan tingkat ketebalan 1,70 mm pada pengukuran bagian kanan dengan kapabilitas proses Cpk 0,3324, bagian kiri dengan kapabilitas proses Cpk 0,3531, bagian tengah dengan kapabilitas proses $\mathrm{Cpm}$ 0,0023, dan bagian panjang dengan kapabilitas proses Cpm 0,9203. Dan pada ketebalan 2,50 $\mathrm{mm}$ pada pengukuran bagian kanan dengan kapabilitas proses Cpm 0,0079, bagian kiri dengan kapabilitas proses Cpk 0,6226, bagian tengah dengan kapabilitas proses Cpk 0,7102, dan bagian panjang dengan kapabilitas proses Cpm 0,3203. Dan adapun Proses pengupasan kayu pada mesin rotary 6 dinyatakan capabel (kemampuan proses baik). Nilai kapabilitas tersebut terlihat pada proses pengupasan kayu dengan tingkat ketebalan 2,50 mm pada pengukuran bagian kanan dengan kapabilitas proses Cpk 1,0944 dan bagian tengah dengan kapabilitas proses Cpk 1,0855. Sedangkan kapabilitas proses rendah terlihat pada nilai indeks kapabilitas pengukuran ketebalan 2,5 mm pada pengukuran bagian kiri dengan kapabilitas proses Cpk 0,8584 dan bagian panjang dengan kapabilitas proses Cpm 0,3664. Dan pada pengukuran ketebalan 1,70 mm bagian kanan dengan kapabilitas proses Cpm 0,0027, bagian kiri dengan kapabilitas proses Cpk 0,4521, bagian tengah dengan kapabilitas proses Cpm 0,0027, dan bagian panjang dengan kapabilitas proses Cpm 0,3642.

\section{DAFTAR PUSTAKA}

Andespa, R. (2010) "Pengertian Pengendalian Kualitas". Retrieved November 01, 2016, From "http://mutiaralumpur.blogspot.co.id/2010/04/pengertian-pengendalian-kualitas.html.

Burhanuddin, M. (2015) "Pengujian Data Pengamatan". Retrieved Desember 20, 2016,Fromhttps://alvinburhani.wordpress.com/2015/12/01/pengujian-data/. 
Gaspersz, V. (2001) “ Metode Analisis Untuk Peningkatan Kualitas”, gramedia pustaka utama, Retrieved November 27, 2016.

Gaspersz, V. (2006) "strategi dramatic reduksi biaya dan pemborosan menggunakan pendekatan Lean - Sigma“. Retrieved November 06, 2016, From https://books.google.co.id/books?id=1S287n-

_eScC\&pg=PT50\&dq=indeks+kapabilitas\&hl=id\&sa=X\&ved=0ahUKEwik9om_rYDQAhU KrY8KHSftCk4Q6AEIJjAD\#v=onepage $\& \mathrm{q}=$ indeks\%20kapabilitas\&f=false 